\title{
The Use of the Liquid from Cashew Nut Shells as an Antioxidant in Biodiesel
}

\author{
Flavio A. Bastos" and Matthieu Tubino* \\ Instituto de Química, Universidade Estadual de Campinas, CP 6154, 13083-970 Campinas-SP, Brazil
}

\begin{abstract}
The influence of cashew nutshell liquid (CNSL) in the oxidative stability of biodiesels prepared from oils of soy, corn, canola and sunflower was studied using the Rancimat method. The induction periods at $110{ }^{\circ} \mathrm{C}$, without and with the addition of CNSL at concentrations of $0.1,0.5$ and $1.0 \% \mathrm{~m} / \mathrm{m}$, were determined and clearly show an important increase in the oxidative stability proportional to the concentration of the additive. For example, with the addition of $0.1 \% \mathrm{~m} / \mathrm{m} \mathrm{CNSL}$, the induction period, in hours, increased from 5.7 to 8.5 (soy biodiesel), from 1.7 to 4.0 (sunflower), from 4.3 to 9.3 (corn) and from 6.9 to 12.8 (canola). The rate constants of the oxidation reactions in presence of CNSL were also determined and their respective values are $\left(\right.$ in $^{-1}$ ): $0.77 \pm 0.08,2.48 \pm 0.46,0.94 \pm 0.08,0.51 \pm 0.11$. The activation parameters (enthalpy, $\Delta \mathrm{H}^{*}$, entropy, $\Delta \mathrm{S}^{*}$, and free energy of activation, $\left.\Delta \mathrm{G}^{*}\right)$ for the oxidation reactions were determined.
\end{abstract}

Keywords: biodiesel, oxidative stability, Rancimat, cashew nutshell liquid, CNSL

\section{Introduction}

Biodiesel was introduced to the Brazilian energy matrix in 2005 by the law No. 11.097 which established the addition of biodiesel to petrol diesel in all Brazilian territory. From 2010, the content of biodiesel in diesel was set at $5 \% \mathrm{~m} / \mathrm{m}$; subsequently, from June $1^{\text {st }} 2014$, this concentration was increased to $6 \% \mathrm{~m} / \mathrm{m}$ and from November $1^{\text {st }} 2014$ to $7 \% \mathrm{~m} / \mathrm{m}$ but the immediate increase to $8 \% \mathrm{~m} / \mathrm{m}$, with a staggered increase up to $10 \%$ in 2019 was already sanctioned. ${ }^{1}$

Biodiesel is a mixture of mono alkyl esters of long chain fatty acids which are synthesized through transesterification reactions of oils and fats with short chain alcohols. ${ }^{2}$ It is miscible with petrol diesel and presents similarities in terms of physical and chemical proprieties, for example, the cetane number, a fact that allows its direct use in diesel engines. $^{3}$

Industrially, biodiesel is mainly prepared through catalytic transesterification using most commonly basic catalysts, but acids can be also used. Among the basic catalysts, sodium hydroxide and sodium methoxide are the most common as they present as advantages in terms of price, the mild conditions of the reaction, and the temperature and atmospheric pressure required, as well as a lower reaction time and higher yield. ${ }^{4}$

*e-mail: tubino@iqm.unicamp.br

\#Present address: Instituto Federal de Educação, Ciência e Tecnologia do Sul de Minas Gerais.
Despite the fact that this kind of catalysis is considered homogeneous, it was recently shown that the catalytic process occurs at the interface of the two phases, i.e., between the oil and the methanol. Therefore, the catalysis of this transesterification reaction can be considered to be heterogeneous. ${ }^{5}$ The reaction occurs in successive and reversible steps forming, progressively, diglycerides, monoglycerides and glycerol. ${ }^{6}$

Nowadays, Brazilian biodiesel production is about 4 billion liters per year, i.e., 4.3 billion liters in 2015 . Of this total, approximately $80 \%$ is prepared from vegetable oils, mainly soy oil that comprises about $98 \%$ of the vegetable oils employed. Animal fats contribute to $17 \%$ of the total. ${ }^{7}$

The national scenario is headed by the Brazilian centralwest region, with 1.4 billion liters, and by the southern regions with about 1.3 billion liters per year. The raw material used for the synthesis of biodiesel varies according to the region (Table 1).

The substitution of fossil fuels by biofuels, even partially, is strongly supported by environmental arguments. Among these: biofuels are renewable, biodegradable, are non-carcinogenic, emit smaller quantities of pollutants and are free of sulfur. ${ }^{8}$ The main challenges nowadays are associated with decreasing the costs of production and with competition from agricultural areas traditionally dedicated to the cultivation of food. ${ }^{6}$

Biodiesel also presents some problems, for example, the emission of nitrogen gases $\left(\mathrm{NO}_{\mathrm{x}}\right)$ by the engines which use such fuel, the absorption of humidity during storage, 
Table 1. Present panorama of the main raw materials used for the production of biodiesel in different regions in Brazil ${ }^{7}$

\begin{tabular}{|c|c|c|c|c|c|}
\hline \multirow{2}{*}{ Raw material } & \multicolumn{5}{|c|}{ Region } \\
\hline & North & Northeast & Central-west & Southeast & South \\
\hline Soy oil / \% & 99.99 & 70.32 & 89.62 & 33.85 & 80.17 \\
\hline Beef tallow / \% & & 27.28 & 6.47 & 55.15 & 16.34 \\
\hline Other $/ \%$ & 0.01 & 2.30 & 3.91 & 11.00 & 3.49 \\
\hline
\end{tabular}

which can cause degradation and oxidative instability due to the presence of unsaturation in the carbon chain of the fatty acids. ${ }^{3}$

The oxidative stability of biodiesel is an important parameter and it is considered in the quality control of this fuel. ${ }^{1}$ Some parameters such as the iodine number, the peroxide number and the acid number as well as viscosity are indicative of the oxidation state of the biodiesel as well as the induction period. ${ }^{9}$

Oxidative stability is an important parameter related to the quality of biodiesel. The oxidative degradation process is influenced by various factors such as the degree of unsaturation of the esters, humidity, temperature,${ }^{10}$ the duration and medium of storage, exposure to air and to light, as well as the presence of metals such as copper, iron, nickel and $\operatorname{tin}^{11}$ which can act as catalysts of the oxidation process, thereby contributing to the degradation of biodiesel.

The degradation of biodiesel results in substances that promote corrosion in the motor and the clogging of filters. These compounds also form deposits in the combustion chamber and in other components of the engine. This leads to a meaningful decrease in the performance of the affected motor. ${ }^{12}$

The oxidation of the biodiesel mainly occurs due to the high degree of unsaturation of the fatty acid molecules which, through the attack of the oxygen from the air, form several products including polymers, alcohols, aldehydes, peroxides and acids, causing an increase in the acid number of the fuel and affecting the viscosity of the fuel. ${ }^{13}$

Fuels obtained from vegetable oils present a higher tendency to oxidize in comparison to those from animal fats, as a function of the predominance of unsaturated chains in their composition. The viscosity of biodiesel increases with an increase in the length of the carbon chain and with its degree of saturation, with consequences on burning in the combustion chamber of the motor. High viscosity causes heterogeneity during combustion due to a decrease in the efficiency of the spray into the combustion chamber, generating the formation of deposits. ${ }^{14}$

The oxidative stability of biodiesel is one of its most important characteristics. Therefore, it is necessary to better understand this property and to find ways to reduce the oxidation of biofuel, allowing for a longer storage period without degradation. In this context, antioxidants can be added to biofuel, as these substances enhance the stability of biodiesel over time.

The process of oxidation occurs in several steps and comprises a series of variables to be considered. It can happen in different ways: by hydrolytic reactions, by enzymatic action, by photo-oxidation and by so-called auto-oxidation. In the hydrolytic case, the reactions can be catalyzed by enzymes along with heat and humidity, ${ }^{15}$ leading to the formation of monoglycerides, diglycerides and of free fatty acids.

In oxidation through the enzymatic pathway, peroxides and hydroperoxides with conjugated double bonds are formed, which can be involved in several degradative reactions. This kind of reaction occurs by the action of lipoxygenase enzymes which act on polyunsaturated fatty acids by catalyzing the addition of oxygen to the chain. Photo-oxidation occurs due to the action of ultraviolet radiation and involves radical reactions with the formation of hydroperoxides which are then degraded to aldehydes, alcohols and hydrocarbons. ${ }^{15}$

The main mechanism of the oxidation of oils and fats is so-called auto-oxidation. ${ }^{16}$ In the first mechanism proposed, ${ }^{17}$ under light and heat, the removal of a hydrogen atom from the allylic carbon occurs, forming an alkylic radical. Sequentially, this free radical reacts with oxygen and is converted to other radicals, and finally the primary products of oxidation appear (peroxides and hydroperoxides); their structure depends on the nature of the fatty acids present. These free radicals remove a hydrogen atom from other molecules, yielding hydroperoxides as the product of primary oxidation and leading to a new radical alkyl which will act as a propagator of the reaction. This results in an autocatalytic process, hence the name autooxidation. In the ramification step, the decomposition of hydroperoxides occurs, leading to an increase in the concentration of free radicals. This decomposition is initially monomolecular but becomes bimolecular when the concentration of hydroperoxide is sufficiently high. ${ }^{17}$ The reaction stops when the radicals react among themselves, forming stable molecules that are secondary products of 
oxidation, for example epoxides, generated by the scission and rearrangement of peroxides. ${ }^{18}$

Antioxidants are generically defined as being substances which, when present in low concentrations in an oxidizable substratum, significantly retard or inhibit oxidation. With respect to the mechanism of action, an antioxidant can be classified as primary, synergistic, oxygen removing, biologic, chelating or mixed. ${ }^{15}$ A primary antioxidant, such as the one used in this work, promotes the removal or inactivation of free radicals that form during the initiation and propagation of the reaction by donating hydrogen atoms to these molecules. This hydrogen is preferably removed from the antioxidant with respect to the allylic hydrogens present in the unsaturation of the fatty acid chains.

Rancimat ${ }^{\circledR}$ is a technique used to determine oxidative stability, expressed in terms of the induction period (IP) of biodiesel, in which rapidly accelerated oxidation is promoted under controlled conditions. Therefore, it is possible to determine this property of a substrate in hours, despite the fact that under natural conditions such oxidation takes months. ${ }^{19}$

In the Rancimat ${ }^{\circledR}$ assay, the determination is performed by monitoring the conductivity of an aqueous solution in which is continuously bubbled with an air flow arising from a cell containing the sample under study. The sample is then oxidized, producing volatile compounds such as formic acid. These compounds are transported by the air flow to the cell that contains high purity water in which they are dissolved, thereby increasing its conductivity, which is then recorded.

Cashew nutshell liquid (CNSL) is a natural product that comes from the shell of the cashew, Anacardium occidentale L., found in the spongy pith of the nut. Figure 1 shows the cross-section of a cashew nut.

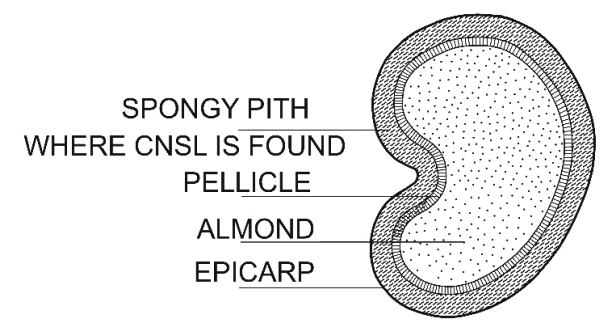

Figure 1. Section cut of a cashew nut.

The cashew originated in the northeast of Brazil. Nowadays, this plant is found in several countries like India, Mozambique, Tanzania, Kenia, Vietnam, Indonesia and Thailand.

In Brazil, the cashew processing industry is localized in the northeastern region, mainly in Ceará State, which is responsible for about $70 \%$ of the Brazilian production, employing directly and indirectly about 300,000 people. Ceará is also the main Brazilian exporter of cashew nuts. ${ }^{20}$

CNSL represents about $25 \%$ of the nut weight and it is considered a subproduct of cashew processing with a very low aggregated value. CNSL can be extracted using a hot or cold process. In the first case, it is obtained by collecting the liquid that drains during the toasting of the nut. Cardol and the cardanol are the major components and they are separated by distillation under reduced pressure (ca. $10 \mathrm{mmHg}$ ). The final liquid contains 15 to $20 \%$ cardol, 60 to $90 \%$ cardanol, about $20 \%$ polymeric material and traces of 2-methylcardol. ${ }^{20}$

Cold processing, where the liquid is extracted with solvents, begins with mechanical cutting and fragmentation of the nutshell. The main components of this liquid are anacardic acid (60 to $70 \%$ ), cardol (20 to $25 \%$ ), cardanol (10\%) and small quantities of 2-methylcardol. ${ }^{21}$ The structural formulas of these compounds are shown in Figure 2.

CNSL is industrially used in several important products such as in rubber as a vulcanizing agent, in polymers as a plasticizer, in epoxy resins as a curing agent, and in varnishes where it confers better resistance to water. ${ }^{21}$

Despite its industrial importance, CNSL is poorly explored commercially in Brazil. It is usually exported at derisory prices..$^{20}$ Chemically, it acts as a free radical scavenger and as a chelating agent by reacting with transition metals in the initiation and propagation steps of the oxidative process. ${ }^{22}$

Based on facts above explained the idea of the present study was born. Therefore, with the purpose to contribute, by one hand, with the Brazilian biodiesel industry and by the other with the cashew industrial activities, the aim of this work was the study of the effect of the CNSL in the oxidative stability of biodiesels prepared from different vegetable oils.

\section{Experimental}

\section{Materials and methods}

To perform the assays on oxidation stability in this work, a method was used that established by the norm EN $14112,{ }^{23}$ known as Rancimat ${ }^{\circledR}$. In this procedure, the sample $(3.0 \mathrm{~g})$ is submitted to a flow of filtered and dried air at a rate of $10 \mathrm{~L} \mathrm{~h}^{-1}$ and at $110^{\circ} \mathrm{C}$.

The action of the oxygen in the air along with high environmental temperature favors oxidation of the sample and, consequently, the formation of products that originate in this reaction, especially low molecular mass volatile organic acids such as formic and acetic acid. These acids 


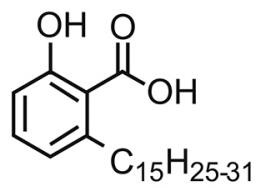

Anacardic acid

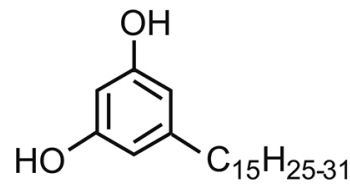

Cardol

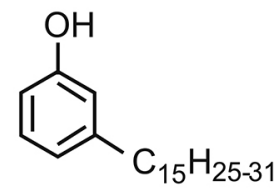

Cardanol

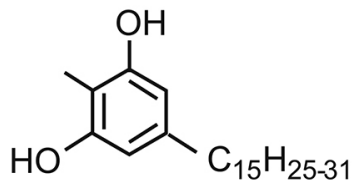

2-methylcardol

$$
\left(-\mathrm{C}_{15} \mathrm{H}_{31}\right)
$$

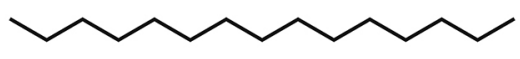

$$
\left(-\mathrm{C}_{15} \mathrm{H}_{29}\right)
$$

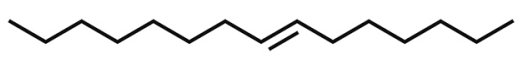

$$
\left(-\mathrm{C}_{15} \mathrm{H}_{27}\right)
$$

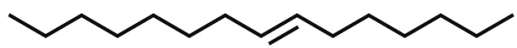

$\left(-\mathrm{C}_{15} \mathrm{H}_{25}\right)$

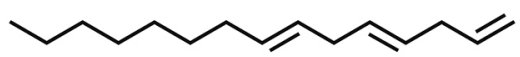

Figure 2. Structural formulas of anacardic acid, cardanol, cardol and 2-methyl cardol, present in CNSL. ${ }^{20}$

are dragged by the air flow being absorbed in another flask containing deionized water with very low conductivity, ca. $0.054 \mu \mathrm{S} \mathrm{cm}^{-1}$. In water, these acids are partially ionized, thereby increasing the conductivity, which is continuously monitored.

The induction period (IP) was determined using the software included with the device, which calculates the second derivative of the conductivity curve versus time. Essentially, the IP corresponds to the time in which the oxidation occurs only to small extent, before the exponential increase..$^{24}$

\section{Thermogravimetric analysis}

The thermic stability of CSNL was determined thermogravimetrically, from 25 to $800{ }^{\circ} \mathrm{C}$ using a TA Instruments model 2050 , with a heating rate of $10^{\circ} \mathrm{C}$ in an argon atmosphere.

\section{Biodiesel synthesis}

The biodiesels used in this work were prepared by alkaline transesterification of vegetable oils of soy, sunflower, corn and canola, purchased at the local market. Enough of each biodiesel was prepared in order to allow the performance of all the necessary analytical measurements with replicates. Transesterification was done by two nucleophilic attacks to the acylglycerides as already described..$^{25}$

\section{CSNL}

The CNSL studied as an antioxidant was applied as extracted from the nutshell without further purification. According to the reported in the literature the CNSL contains about $70 \%$ of cardanol. ${ }^{20}$

\section{Samples}

To known quantities of the samples of each biodiesel, with the aid of an analytical balance, were added quantities of CNSL in order to obtain solutions at the following concentrations: $0.0,0.5$ and $1.0 \% \mathrm{~m} / \mathrm{m}$. Complete dissolution was obtained with the aid of an ultrasonic bath, after 3 to 10 minutes of sonication, according to the studied biodiesel and the concentration of CNSL.

Beyond the temperature of $110^{\circ} \mathrm{C}$, specified in norm EN $14112,{ }^{23}$ experiments were also done at 120 and at $130{ }^{\circ} \mathrm{C}$, with the aim of obtaining the mathematical correlation between IP and temperature which allows for the estimation, through extrapolation, of the IP at $25^{\circ} \mathrm{C}$.

From these experimental data, it was also possible to calculate the overall constant of the induction reactions. All determinations performed in the Rancimat ${ }^{\circledR}$ were done in quadruplicate.

\section{Results and Discussion}

Thermogravimetric analysis

Through the thermogravimetric analysis results, which can be seen in Figure 3, it is possible to conclude that the CNSL is stable up to about $170{ }^{\circ} \mathrm{C}$. This fact clearly indicates that in the Rancimat ${ }^{\circledR}$ experiments performed between 110 and $130{ }^{\circ} \mathrm{C}$, no thermic decomposition of the antioxidant occurred.

Influence of temperature and of the concentration of CNSL on the IP value

The initial step of the oxidation of the sample, where the formation of peroxides mainly occurs, is slow such 


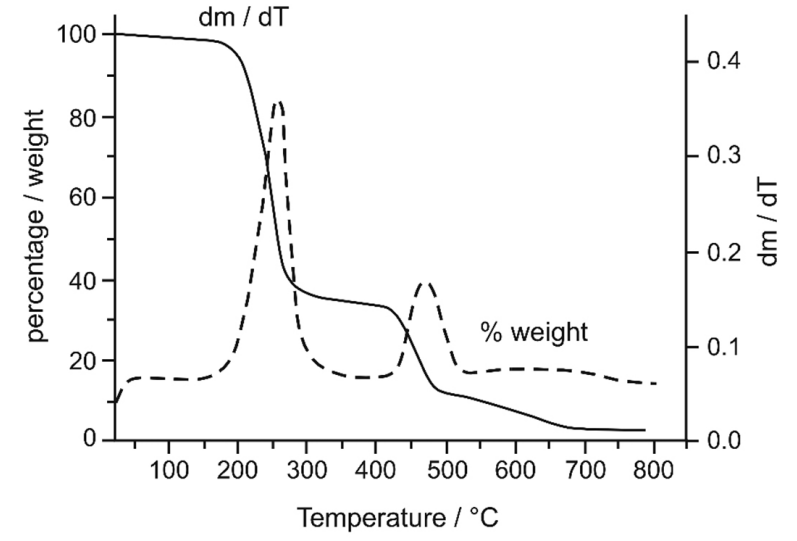

Figure 3. Thermogravimetric analysis graph of the CNSL.

that the increase in conductivity is also small at this stage. The oxidation process is gradually accelerated, forming secondary products such as aldehydes, alcohols and organic acids of low molecular mass, such as formic acid. This reflects the exponential increase in conductivity. ${ }^{24}$

The values of the induction period (IP) of the prepared biodiesels, at the temperatures of 110,120 and $130^{\circ} \mathrm{C}$ and with different concentrations of CNSL, are presented in Table 2.

As can be seen in Table 2, the increase in temperature leads to the reduction of the induction period, which was expected, since the oxidation process is accelerated by increase in temperature. ${ }^{11}$
Also, when comparing the IP values at a given temperature, it is observed that the higher the concentration of the CNSL, the greater is the value of IP, fact that clearly proves its antioxidant action.

From the data in Table 2 for each biodiesel, equation 1 was used to describe the parameters, shown in Table 3, to assess the linear correlation between the natural logarithm of IP, In IP, versus the temperature in degrees Celsius.

$\ln \mathrm{IP}=\mathrm{a}+\mathrm{bt}$

From equation 1 , the IP at $25^{\circ} \mathrm{C}$ can be obtained by extrapolation for the biodiesels prepared from each oil. The IP values at $25{ }^{\circ} \mathrm{C}$ show more clearly the period during which the biodiesel can be stored at environmental temperature before reaching the accelerated oxidation phase. ${ }^{26}$ The results can be seen in Table 4 . In all cases reported in this table it was observed that the IP increases with the addition of CNSL. For example, with $0.5 \% \mathrm{~m} / \mathrm{m}$ of addition, the IP of the studied biodiesels increased about 2.5 times (sunflower), 3.9 times (corn), 2.5 times (soy) and 2.7 times (canola) with respect to biodiesel without CNSL.

Table 5 shows the mean fatty acid concentrations in the oils used in this work, according to ANVISA. ${ }^{27}$ Keeping in mind that these concentrations, in $\% \mathrm{~m} / \mathrm{m}$, were similar for the biodiesels prepared from these oils, the data in this

Table 2. Values of the induction period (IP) in hours for the different synthesized biodiesels, at 110,120 and $130^{\circ} \mathrm{C}$, with different concentrations of CNSL

\begin{tabular}{|c|c|c|c|c|}
\hline \multirow{2}{*}{ Biodiesel source } & \multirow{2}{*}{$\mathrm{CNSL} / \%(\mathrm{~m} / \mathrm{m})$} & \multicolumn{3}{|c|}{ Temperature $/{ }^{\circ} \mathrm{C}$} \\
\hline & & 110 & 120 & 130 \\
\hline \multirow{4}{*}{ Sunflower } & 0.0 & $1.67 \pm 0.03$ & $0.80 \pm 0.06$ & $0.47 \pm 0.08$ \\
\hline & 0.1 & $3.03 \pm 0.17$ & $1.57 \pm 0.03$ & $0.80 \pm 0.04$ \\
\hline & 0.5 & $3.53 \pm 0.16$ & $1.81 \pm 0.06$ & $0.98 \pm 0.01$ \\
\hline & 1.0 & $3.97 \pm 0.08$ & $2.03 \pm 0.01$ & $1.09 \pm 0.02$ \\
\hline \multirow{4}{*}{ Corn } & 0.0 & $4.33 \pm 0.18$ & $2.20 \pm 0.25$ & $1.25 \pm 0.07$ \\
\hline & 0.1 & $6.80 \pm 0.63$ & $3.11 \pm 0.33$ & $1.65 \pm 0.08$ \\
\hline & 0.5 & $8.35 \pm 0.28$ & $4.04 \pm 0.14$ & $2.01 \pm 0.03$ \\
\hline & 1.0 & $9.27 \pm 0.35$ & $4.87 \pm 0.11$ & $2.32 \pm 0.07$ \\
\hline \multirow{4}{*}{ Soy } & 0.0 & $5.66 \pm 0.10$ & $3.00 \pm 0.05$ & $1.61 \pm 0.03$ \\
\hline & 0.1 & $5.52 \pm 0.21$ & $2.87 \pm 0.08$ & $1.53 \pm 0.03$ \\
\hline & 0.5 & $7.36 \pm 0.06$ & $3.60 \pm 0.04$ & $1.86 \pm 0.05$ \\
\hline & 1.0 & $8.53 \pm 0.10$ & $4.26 \pm 0.08$ & $2.09 \pm 0.12$ \\
\hline \multirow{4}{*}{ Canola } & 0.0 & $6.87 \pm 0.64$ & $3.63 \pm 0.15$ & $1.95 \pm 0.03$ \\
\hline & 0.1 & $8.27 \pm 0.34$ & $4.26 \pm 0.19$ & $2.12 \pm 0.14$ \\
\hline & 0.5 & $10.62 \pm 0.10$ & $5.39 \pm 0.13$ & $2.66 \pm 0.08$ \\
\hline & 1.0 & $12.79 \pm 0.40$ & $6.66 \pm 0.20$ & $3.35 \pm 0.09$ \\
\hline
\end{tabular}

CNSL: cashew nutshell liquid. 
Table 3. Linear and angular coefficients of the equation 1 applied for the four prepared biodiesels in the absence and presence of various concentrations of CNSL

\begin{tabular}{lccc}
\hline CNSL / \% $(\mathrm{m} / \mathrm{m})$ & $\mathrm{a}$ & $\mathrm{b}$ & Pearson's R \\
\hline \multicolumn{4}{c}{ Biodiesel from soy oil } \\
\hline 0.0 & $8.645 \pm 0.038$ & $-0.06285 \pm 0.00032$ & -0.99999 \\
0.1 & $8.749 \pm 0.067$ & $-0.06407 \pm 0.00054$ & -0.99996 \\
0.5 & $9.727 \pm 0.186$ & $-0.07031 \pm 0.00162$ & -0.99874 \\
1.0 & $9.824 \pm 0.058$ & $-0.06980 \pm 0.00051$ & -0.99997 \\
\hline \multicolumn{5}{c}{ Biodiesel from corn oil } \\
\hline 0.0 & $10.628 \pm 0.207$ & $-0.08360 \pm 0.00173$ & -0.99979 \\
0.1 & $9.566 \pm 0.387$ & $-0.06979 \pm 0.00310$ & -0.99902 \\
0.5 & $9.907 \pm 0.055$ & $-0.07083 \pm 0.00043$ & -0.99998 \\
1.0 & $9.995 \pm 0.416$ & $-0.07027 \pm 0.00343$ & -0.99881 \\
\hline \multicolumn{5}{c}{ Biodiesel from sunflower oil } \\
\hline 0.0 & $8.176 \pm 0.538$ & $-0.06970 \pm 0.00486$ & -0.99758 \\
0.1 & $8.517 \pm 0.196$ & $-0.06500 \pm 0.00163$ & -0.99968 \\
0.5 & $8.148 \pm 0.200$ & $-0.06284 \pm 0.00156$ & -0.99969 \\
1.0 & $8.517 \pm 0.196$ & $-0.06500 \pm 0.00163$ & -0.99968 \\
\hline \multicolumn{5}{c}{ Biodiesel from canola oil } \\
\hline 0.0 & $8.759 \pm 0.033$ & $-0.06223 \pm 0.00026$ & -0.99999 \\
0.1 & $9.539 \pm 0.155$ & $-0.06749 \pm 0.00132$ & -0.99981 \\
0.5 & $9.917 \pm 0.061$ & $-0.06869 \pm 0.00054$ & -0.99997 \\
1.0 & $9.927 \pm 0.139$ & $-0.06700 \pm 0.00115$ & -0.99985 \\
\hline CNSL & & & \\
\hline
\end{tabular}

CNSL: cashew nutshell liquid.

Table 4. Values of the induction periods, in days, at $25^{\circ} \mathrm{C}$ for the studied biodiesels at different CNSL concentrations

\begin{tabular}{lcccc}
\hline \multirow{2}{*}{$\begin{array}{l}\text { Biodiesel } \\
\text { from oil of }\end{array}$} & \multicolumn{4}{c}{ CNSL concentration / \% (m/m) } \\
\cline { 2 - 5 } & 0.0 & \multicolumn{4}{c}{0.1} & 0.5 & 1.0 \\
\hline Sunflower & $16 \pm 2$ & $30 \pm 1$ & $40 \pm 1$ & $41 \pm 1$ \\
Corn & $36 \pm 2$ & $104 \pm 2$ & $142 \pm 1$ & $157 \pm 2$ \\
Soy & $49 \pm 1$ & $53 \pm 2$ & $120 \pm 1$ & $134 \pm 1$ \\
Canola & $56 \pm 1$ & $107 \pm 1$ & $152 \pm 1$ & $160 \pm 1$ \\
\hline
\end{tabular}

CNSL: cashew nutshell liquid; IP: induction period.

table can be used for preliminary comparative purposes of the oxidation properties of the studied biodiesels.

According to the data in Table 2, it is easy to observe that among the biodiesels without the antioxidant added, the sunflower derivative presented the lowest IP values. This can be attributed to the higher concentration of linoleic acid (C18:2) present in this biodiesel with respect to the others studied in this work.

Linoleic acid is more reactive that the oleic acid because it has a methylenic bis-allylic site at carbon 11, between two double bonds, which can easily lose a hydrogen atom. The removal of a hydrogen from the carbon at position 11 of linoleic acid produces a hybrid pentadienyl radical that is stabilized by resonance. The dienoic hydroperoxides that result are stabilized by conjugation,${ }^{28}$ as can be seen in Figure 4.

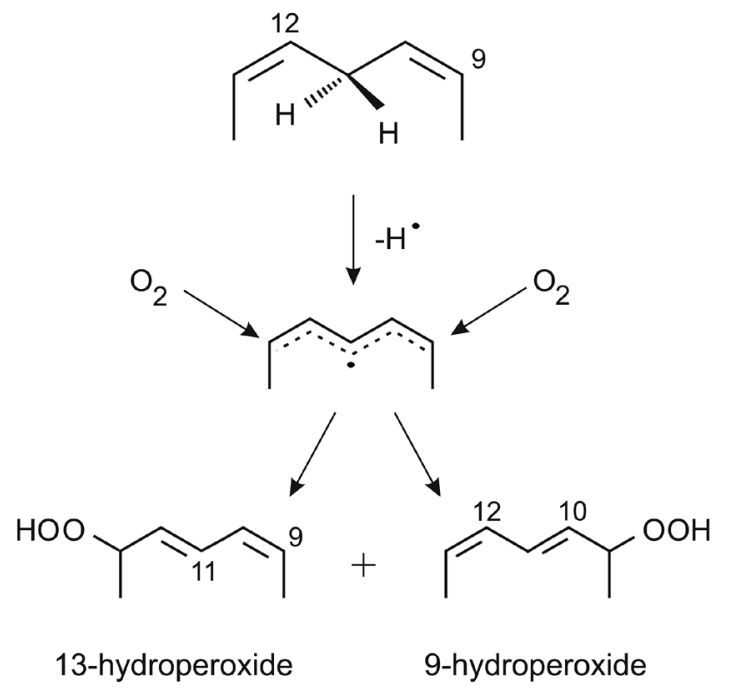

Figure 4. Scheme of the reaction of linoleate oxidation. ${ }^{17}$

In a mechanistic proposal, the radical pentadienyl assumes four conformations which react with oxygen. ${ }^{28}$ The reaction sequence is shown in Figure 5.

Linoleate, at a concentration up to $75 \%$ in sunflower oil, is about 40 times more reactive than oleate. ${ }^{29}$ In sequence, also presenting species 18:2 and 18:1, but at lower concentrations, are the biodiesels obtained from corn, soy and canola oil, which presented longer induction periods, reflecting a compromise between the unsaturated character and the stability to oxidation.

Table 5. Range of the mean composition in $\% \mathrm{~m} / \mathrm{m}$ of fatty acids in the oils used for biodiesel synthesis ${ }^{27}$

\begin{tabular}{lcccccc}
\hline & \multicolumn{5}{c}{ Fatty acid composition of the oils / \% (m/m) } \\
\cline { 2 - 7 } Oil & $\begin{array}{c}\text { Palmitic }^{\mathrm{a}} \\
(16: 0)\end{array}$ & $\begin{array}{c}\text { Stearic } \\
(18: 0)\end{array}$ & $\begin{array}{c}\text { Oleic }^{\mathrm{a}} \\
(18: 1)\end{array}$ & $\begin{array}{c}\text { Linoleic }^{\mathrm{a}} \\
(18: 2)\end{array}$ & $\begin{array}{c}\text { Linolenic }^{\mathrm{a}} \\
(18: 3)\end{array}$ & $\begin{array}{c}\text { Erucic }^{\mathrm{a}} \\
(22: 1)\end{array}$ \\
\hline Sunflower & $3.0-10$ & $1.0-10$ & $14-35$ & $55-75$ & $<0.3$ & $<0.5$ \\
Corn & $9.0-14$ & $0.5-4.0$ & $24-42$ & $34-62$ & $<2.0$ & - \\
Soy & $7.0-14$ & $1.4-5.5$ & $19-30$ & $44-62$ & $4.0-11$ & - \\
Canola & $2.5-6.5$ & $0.8-3.0$ & $53-70$ & $15-30$ & $5.0-13$ & $<2.0$ \\
\hline
\end{tabular}

$\mathrm{a}(\mathrm{n}: \mathrm{m})$ where $\mathrm{n}=$ number of carbon atoms in the molecule and $\mathrm{m}=$ number of carbon to carbon double bonds in the molecule; CNSL: cashew nutshell liquid. 


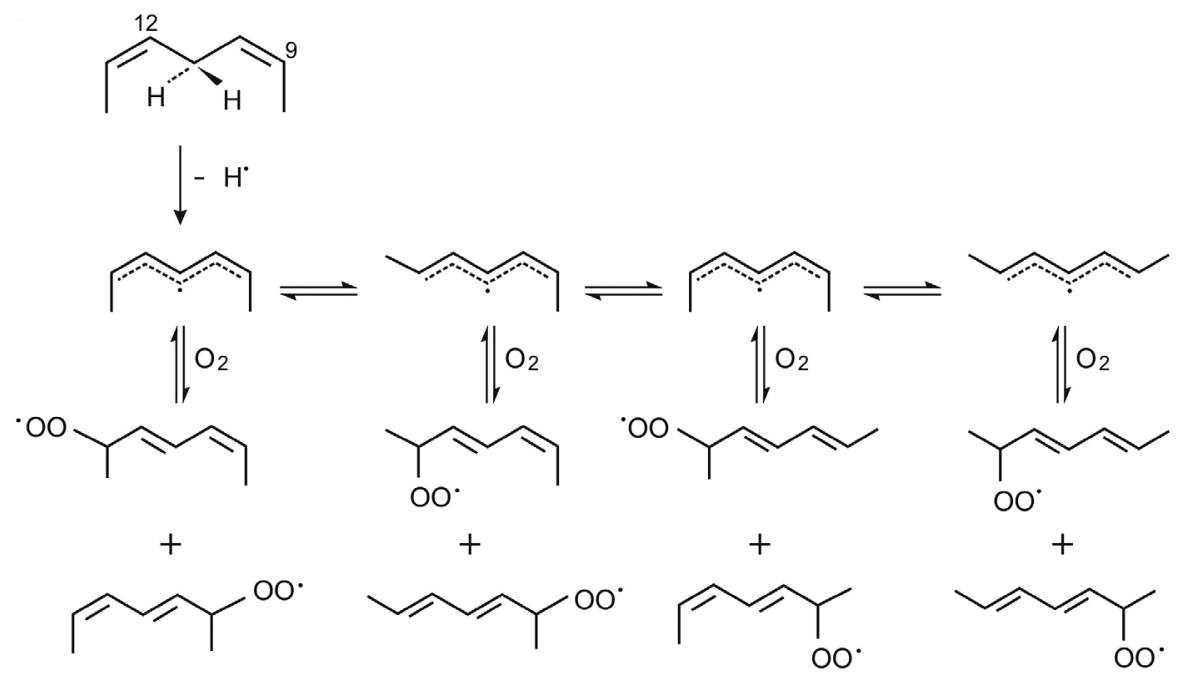

Figure 5. Scheme of the mechanism proposal of the reaction of the radical pentadienyl with molecular oxygen. ${ }^{30}$

\section{Calculation of the reaction rate constants}

As it can be seen in Tables 2 and 3, the IP increased with an increase in the concentration of the antioxidant. Considering the period of induction and assuming a pseudo first order model, the rate constant of the total reaction in the initiation step of oxidation was calculated.

Despite the complexity of the reaction and the simplicity of the pseudo first order model, surprisingly, it worked well. In this model, the natural logarithm of the induction period of the monitored species, measured by conductivity, correlated linearly with the CNSL concentration (equation 2). The angular coefficient of this curve is the first order rate constant which is expressed as time $e^{-1}$.

$\ln \mathrm{C}-\ln \mathrm{C}_{\lim }=\mathrm{k}\left(\mathrm{IP}_{\mathrm{i}}-\mathrm{IP}_{0}\right)$

In equation $2, \mathrm{IP}_{\mathrm{i}}$ is the induction period at concentration $\mathrm{i}$ and $\mathrm{IP}_{0}$ is induction period in the absence of the antioxidant. $\mathrm{C}$ is the concentration of the antioxidant; $\mathrm{C}_{\lim }$ is the calculated limit concentration below which the action of the antioxidant can be considered negligible, i.e., $\mathrm{IP}_{\mathrm{i}}=\mathrm{IP}_{\mathrm{o}}$ and $\mathrm{C}=\mathrm{C}_{\mathrm{lim}}$; $\mathrm{k}$ is the pseudo first order rate constant of the oxidation reaction of CNSL. Actually, in the Rancimat ${ }^{\circledR}$ method, the formation of volatile acids is monitored, which are detected by the conductivity of the water in which they are absorbed. Therefore, the oxidation of CNLS is measured indirectly. As the IP is a reflection of the rate of the oxidation reaction, the action of the antioxidant reduces the IP, i.e., there is a direct correlation between the natural logarithm of the concentration, $\ln \mathrm{C}$, of the CNLS and the increasing $\left(\mathrm{IP}_{\mathrm{i}}-\mathrm{IP}_{0}\right)$ of the IP, as expressed by equation 3 .

Equation 2 above can be rewritten as equation 3 : $\ln \mathrm{C}=\mathrm{k}\left(\mathrm{IP}_{\mathrm{i}}-\mathrm{IP}_{0}\right)+\ln \mathrm{C}_{\text {lim }}$

From equation 3 , the pseudo first order rate constant, $\mathrm{k}$, and the $\mathrm{C}_{\lim }$ can be obtained, respectively, from the slope and from the linear coefficient. ${ }^{31}$

The values of the pseudo first order rate constants, $\mathrm{k}$, and the limit concentration $\mathrm{C}_{\text {lim }}$, calculated through the equation 3 , at 110,120 and $130{ }^{\circ} \mathrm{C}$, for the biodiesels obtained from sunflower, corn, soy and canola oil, with the addition of CNSL, can be seen in Table 6.

With respect to the limit concentrations of CNSL, the values are low, indicating the excellent reactivity of CNSL towards free radicals. In Table 7, a comparison is shown between the IP values and the respective constant rates, $\mathrm{k}$, of the reaction at $110^{\circ} \mathrm{C}$. As expected, a linear relation between these two parameters was observed, i.e., the reaction constant values increased with a decrease in the IP value. This correlation is described by equation 4 .

$\mathrm{k}=(3.07 \pm 0.45)-(0.048 \pm 0.011) \mathrm{IP}$

(Pearson's R $=-0.954$ )

Considering that the oxidation process is associated with the formation of free radicals, smaller IP values suggest that a higher quantity of these radicals react with molecules of the antioxidant, leading to higher reaction constant values.

Determination of the changes of enthalpy, entropy and free energy of activation

The changes in enthalpy, $\Delta \mathrm{H}^{*}$, entropy, $\Delta \mathrm{S}^{*}$, and free energy of activation, $\Delta \mathrm{G}^{*}$, can be calculated through the equation of Eyring (equation 5), where $\mathrm{k}_{\mathrm{b}}$ is the Boltzman 
Table 6. Pseudo first order rate constants, $\mathrm{k}$, and limit concentration, $\mathrm{C}_{\mathrm{lim}}$, calculated through the equation 3 for biodiesels prepared from sunflower, corn, soy and canola oil, with the addition of CNSL

\begin{tabular}{|c|c|c|c|c|c|}
\hline & \multirow{2}{*}{ Temperature $/{ }^{\circ} \mathrm{C}$} & \multicolumn{4}{|c|}{ Biodiesel source } \\
\hline & & Sunflower & Corn & Soy & Canola \\
\hline \multirow{3}{*}{$\mathrm{k} / \mathrm{h}^{-1}$} & 110 & $2.47 \pm 0.47$ & $0.94 \pm 0.08$ & $0.77 \pm 0.08$ & $0.51 \pm 0.10$ \\
\hline & 120 & $5.03 \pm 1.02$ & $1.32 \pm 0.26$ & $1.67 \pm 0.33$ & $0.95 \pm 0.25$ \\
\hline & 130 & $8.04 \pm 0.70$ & $3.46 \pm 0.64$ & $4.16 \pm 0.51$ & $1.83 \pm 0.56$ \\
\hline \multirow{3}{*}{$\mathrm{C}_{\text {lim. }} / \%(\mathrm{~m} / \mathrm{m})$} & 110 & $(3.94 \pm 0.01) \times 10^{-3}$ & $(0.01 \pm 0.01)$ & $(0.12 \pm 0.06)$ & $(0.06 \pm 0.03)$ \\
\hline & 120 & $(6.32 \pm 0.01) \times 10^{-5}$ & $(0.03 \pm 0.02)$ & $(0.15 \pm 0.03)$ & $(0.07 \pm 0.04)$ \\
\hline & 130 & $(7.37 \pm 0.01) \times 10^{-3}$ & $(0.03 \pm 0.02)$ & $(0.15 \pm 0.05)$ & $(0.09 \pm 0.06)$ \\
\hline \multirow{3}{*}{$\mathrm{R}^{\mathrm{a}}$} & 110 & 0.929 & 0.987 & 0.981 & 0.919 \\
\hline & 120 & 0.920 & 0.926 & 0.970 & 0.868 \\
\hline & 130 & 0.985 & 0.934 & 0.970 & 0.830 \\
\hline
\end{tabular}

${ }^{\mathrm{a}} \mathrm{R}=$ correlation coefficient.

Table 7. Comparison among the values of the rate constants and the induction period of oxidation, at $25^{\circ} \mathrm{C}$, for the biodiesels from sunflower, corn, soy and canola oil

\begin{tabular}{|c|c|c|c|c|}
\hline & Sunflower & Corn & Soy & Canola \\
\hline $\mathrm{k} / \mathrm{h}^{-1}$ & $2.48 \pm 0.46$ & $0.94 \pm 0.08$ & $0.77 \pm 0.08$ & $0.51 \pm 0.11$ \\
\hline $\mathrm{IP} / \mathrm{h}$ & $16 \pm 2$ & $36 \pm 2$ & $49 \pm 1$ & $56 \pm 1$ \\
\hline
\end{tabular}

IP: induction period.

constant, $\mathrm{h}$ is the Planck constant and $\mathrm{T}$ is the absolute temperature.

$\mathrm{k}=\left(\mathrm{k}_{\mathrm{b}} / \mathrm{h}\right) \mathrm{Te}^{\Delta \mathrm{S} * / \mathrm{R}} \mathrm{e}^{-\left(\Delta \mathrm{H}^{*} / \mathrm{RT}\right)}$

Applying logarithms to the equation 5, the correlation is linearized and the equation 6 is obtained.

$\ln (\mathrm{k} / \mathrm{T})=\left[\ln \left(\mathrm{k}_{\mathrm{b}} / \mathrm{h}\right)+(\Delta \mathrm{S} * / \mathrm{R})\right]-\left(\Delta \mathrm{H}^{*} / \mathrm{R}\right) 1 / \mathrm{T}$

From the linear correlation of $\ln \mathrm{k} / \mathrm{T}$ versus $1 / \mathrm{T} \Delta \mathrm{H}^{*}$, $\Delta \mathrm{S}^{*}$ and therefore $\Delta \mathrm{G}^{*}\left(\Delta \mathrm{G}^{*}=\Delta \mathrm{H}^{*}-\mathrm{T} \Delta \mathrm{S}^{*}\right)$ can determined in the desired temperature. Table 8 shows these values and the respective Pearson's linear coefficient of correlation of the curve.

Considering the negative values of entropy, it can be supposed that an associative mechanism of reaction is operational in the initial period of oxidation of a biodiesel, mainly in the cases of the biodiesels which were prepared from sunflower, corn and canola oil. In the case of the biodiesel from soy oil, inferring from the $\Delta \mathrm{H}^{*}$ higher value and the relatively lower $\Delta \mathrm{S}^{*}$ value, it seems that a dissociative contribution occurred. Combining the $\Delta \mathrm{S}^{*}$ and $\Delta \mathrm{H}^{*}$ contributions, an associative interchange can be suggested in the case of the initial period of oxidation of the biodiesel obtained from soy oil. In any case, it is evident that this period of the oxidation process is dependent on the magnitude of $\Delta \mathrm{G}^{*}$, which represents a compromise between the enthalpy and entropy variations of the reaction. The $\Delta \mathrm{G}^{*}$ of the initial oxidation of the biodiesels from sunflower, corn and canola oil correlates linearly with the IP (Pearson's R = 0.944), indicating that the same mechanism occurred in these three cases. For the biodiesel from soy oil, it did not obey the same correlation, indicating a different reaction mechanism.

\section{Conclusions}

From these results, it can be concluded that CNSL

Table 8. Values of $\Delta \mathrm{H}^{*}, \Delta \mathrm{S}^{*}$ and $\Delta \mathrm{G}^{*}$ for the induction reaction of oxidation of the biodiesels obtained from sunflower, corn, soy and canola oil

\begin{tabular}{|c|c|c|c|c|c|}
\hline Biodiesel from oil of & $\Delta \mathrm{S}^{*} /\left(\mathrm{J} \mathrm{mol}^{-1} \mathrm{~K}^{-1}\right)$ & $\Delta \mathrm{H}^{*} /\left(\mathrm{kJ} \mathrm{mol}^{-1}\right)$ & Correlation coefficient, $\mathrm{R}$ & $\Delta \mathrm{G}^{* \mathrm{a}} /\left(\mathrm{kJ} \mathrm{mol}^{-1}\right)$ & $\mathrm{IP}^{\mathrm{a}} / \mathrm{h}$ \\
\hline Sunflower & $-14.1 \pm 2.2$ & $74.0 \pm 0.9$ & 0.981 & $108.0 \pm 2.4$ & $16 \pm 2$ \\
\hline Corn & $-108.1 \pm 7.6$ & $79.9 \pm 3.0$ & 0.824 & $112.1 \pm 8.2$ & $36 \pm 2$ \\
\hline Soy & $-44.4 \pm 2.0$ & $104.6 \pm 0.8$ & 0.992 & $117.8 \pm 2.2$ & $49 \pm 1$ \\
\hline Canola & $-115.3 \pm 0.7$ & $78.7 \pm 0.3$ & 0.998 & $113.1 \pm 0.8$ & $56 \pm 1$ \\
\hline
\end{tabular}

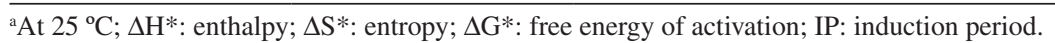


liquid can be used as an antioxidant in biodiesel. Small concentrations as $0.1 \% \mathrm{~m} / \mathrm{m}$ or less are enough to increase the IP, thereby extending the stability of the biofuel. The inverse correlation between the IP values and the calculated values of the rate constant of the reaction, $\mathrm{k}$, through equation 3 , clearly indicates that the added CNSL reacts with the free radicals formed in the oxidation process, leading, as a consequence, to the increase of the oxidation stability. With respect to the parameters of activation determined in this work, they allowed to suppose that a dissociative mechanism contributes for the oxidation reaction.

Considering the low cost of the CNSL, the increase to the final biodiesel price will be almost insignificant. It must also be remembered that this liquid is of vegetal origin, meaning that its use will be not harmful to the environment.

\section{Acknowledgments}

The authors would like to thank the Conselho Nacional de Pesquisa Científica e Tecnológica, CNPq, the Coordenação de Aperfeiçoamento de Pessoal de Nível Superior, CAPES, for financial support and to Prof Adilson Beatriz, of the Federal University of Mato Grosso do Sul for the generous donation of the cashew nut shell liquid.

\section{References}

1. Lei No. 13.263, de 23 de Março de 2016, Dispõe sobre os Percentuais de Adição de Biodiesel ao Óleo Diesel Comercializado no Território Nacional; http://www.planalto. gov.br/ccivil_03/_Ato2015-2018/2016/Lei/L13263.htm, accessed in July 2016.

2. Demirbas, A.; Energy Sources 2009, 31, 889.

3. Knothe, G.; Gerpen, J. V.; Krahl, J.; Ramos, L. P.; Manual de Biodiesel, $1^{\text {a }}$ ed.; Edgard Blücher Ltda.: Curitiba, Brasil, 2006.

4. Schwab, A. W.; Bagby, M. O.; Freedman, B.; Fuel 1987, 66, 1372.

5. Tubino, M.; Rocha Jr., J. G.; Bauerfeldt, G. F.; Fuel 2014, 125, 164.

6. Suarez, P. A.; Santos, A. L. F.; Rodrigues, J. P.; Alves, M. B.; Quim. Nova 2009, 32, 768.

7. http://www.anp.gov.br/?pg=79124\&m=\&t1=\&t2=\&t3=\&t4= $\& a r=\& p s=\& 1454065353626$, Rio de Janeiro, accessed in July 2016.

8. Russo, D.; Dassisti, M.; Lawlor, V.; Olabir, A. G.; Renewable Sustainable Energy Rev. 2012, 16, 4056.

9. Zuleta, E. C.; Baena, L.; Rios, L. A.; Calderón, J. A.; J. Braz. Chem. Soc. 2012, 23, 2159.

10. Maia, E. C. R.; Borsato, D.; Moreira, I.; Spacino, K. R.; Rodrigues, P. R. P.; Gallina, A. L.; Fuel Process. Technol. 2011, 92, 1750.
11. Sarin, A.; Arora, R.; Singh, N. P.; Sharma, M.; Malhota, R. K.; Energy 2009, 34, 1271.

12. Yamane, K.; Kawasaki, K.; Sone, K.; Hara, T.; Int. J. Engine Res. 2007, 8, 307.

13. Ferrari, R. A.; Oliveira, V. D.; Scabio, A.; Sci. Agric. 2005, 62, 291.

14. Lôbo, I. P.; Ferreira, S. L.; Quim. Nova 2009, 32, 1596.

15. Ramalho, V. C.; Jorge, N.; Quim. Nova 2006, 29, 765.

16. Farmer, E. H.; Bloomfield, G. G.; Sundralingam, S.; Sutton, D. A.; Trans. Faraday Soc. 1942, 38, 348.

17. Marquéz-Ruiz, G.; Holgado, F.; Velasco, J.; Food Oxidants and Antioxidants: Chemical, Biological and Functional Properties, $1^{\text {st }}$ ed.; CRC Press: Boca Raton, USA, 2013.

18. Silva, F. A. M.; Borges, M. F. M.; Ferreira, M. A.; Quim. Nova 1999, 22, 94.

19. Hamilton, R. J.; Allen, J. C.; Rancidity in Foods, $3^{\text {rd }}$ ed.; Aspen Publishers Inc.: Maryland, USA, 1999.

20. Mazzetto, S. E.; Lomonaco, D.; Quim. Nova 2009, 32, 732.

21. Paramshivappa, R.; Kumar, P. P.; Vithayathil, P. J.; Rao, A. S.; J. Agric. Food Chem. 2001, 49, 2548.

22. de Sousa, C. M.; Silva, H. R., Vieira Jr., G. M. V.; Ayres, M. C. C.; da Costa, C. L. S.; Araújo, D. S.; Cavalcante, L. C. D.; Barros, E. D. S.; Araújo, P. B. M.; Brandão, M. S.; Chaves, B.; Chaves, M.; Quim. Nova 2007, 30, 351.

23. http://www.en-standard.eu/csn-en-14112-fat-and-oilderivatives-fatty-acid-methyl-esters-fame-determinationof-oxidation-stability-accelerated-oxidationtest/?gclid=CIeistO3oM4CFUYIkQod8SYFsg, accessed on August 1, 2016.

24. Pullen, J.; Saeed, K.; Renewable Sustainable Energy Rev. 2012, 16, 5924.

25. Boog, J. H. F.; Silveira, E. L.; de Caland, L. B.; Tubino, M.; Fuel 2011, 90, 905.

26. Gan, L. H.; Ooi, K. S.; Gan, L. M.; Goh, S. H.; J. Am. Oil Chem. Soc. 1995, 72, 439.

27. http://portal.anvisa.gov.br/documents/33880/2568070/ RES_482_1999.pdf/d4483adc-about 98\% of the vegetable oils employed.812b-425a-a400-ae93891d6514, accessed in July 2016; O'Brien, R. D.; Fats and Oils: Formulating and Processing for Applications, $2^{\text {nd }}$ ed.; CRC Press LLC: Florida, EUA, 2004, ch. 1.

28. Frankel, E. N.; Lipid Oxidation, $2^{\text {nd }}$ ed.; The Oil Press: Philadelphia, USA, 2005.

29. Knothe, G.; Dunn, R. O.; J. Am. Oil Chem. Soc. 2003, 80, 1021.

30. Porter, N. A.; Wolf, R. A.; Weenen, H.; Lipids 1980, 15, 163.

31. Xin, J.; Imahara, H.; Saka, S.; Fuel 2009, 88, 282.

Submitted: May 3, 2016

Published online: August 2, 2016

FAPESP has sponsored the publication of this article. 